\title{
Calculation and Design of the Wooden Lens-Shaped Truss with the Value of Snow Load on the Horizontal Ground Surface 3.2 Kpa
}

\author{
Sabina M. Rzaeva ${ }^{1}$, Svetlana V. $\overline{\text { Zonina }^{2}}, \overline{\text { Lida A. Feoknistova }^{3} \text {, Tatiana V. Rzaeva }}{ }^{4}$ \\ ${ }^{1}$ Kazan Federal University, Naberezhnye Chelny Institute, Engineering-Economic College \\ ${ }^{2,3,4}$ Kazan Federal University, Naberezhnye Chelny Institute \\ *Email: tania14.11@mail.ru, Contact:89046612655
}

Received: 21st October 2017 Accepted: 16th November 2017, Published: 31st December 2017

\begin{abstract}
In this paper, they considered the algorithm for a lenticular shaped truss calculation, in accordance with the set of rules "Wooden glued and all-wood structures" SNiP II - 25 - 80 (CR 64.13330 - 2011).

The results of load calculation concerning the own weight of the truss, the calculation of the uniformly distributed constant load located on the whole span, the calculation of the distributed snow load with the triangular outline are presented. The calculated forces in the elements of the truss are determined by the methods of knot cutting out, the longitudinal forces $\mathrm{N}$ and the bending moments $\mathrm{M}$ are calculated in the upper belt panels. The section of the truss is selected and checked. The result of the above calculations is a positive evaluation of a building design possibility with the span of $24 \mathrm{~m}$ at the calculation of the load-bearing structures for the maximum possible loads, where a wooden segmented lens-shaped truss is proposed as a cover.
\end{abstract}

Keywords: Glued Wood, Lens-Shaped Truss, Building Structures, The Structures Without Bars, Distributive Snow Load.

\section{Introduction}

Every year in our country and throughout the world [1] the production of glued timber increases. The structures of glued wood are used for the frameworks of buildings and structures of various functional purposes. Accordingly, the range of load-bearing wooden structures is constantly expanding by the improvement of known and the development of fundamentally new constructive solutions. The types of the structures without bars are of interest along with arched covers and frames. One of the most effective ones, especially for large spans, is the truss with curved belts, the so-called lens-shaped one [2,8].

If we compare lens-shaped trusses with other types, the lens-shaped have a number of features and advantages, for example, they differ by a relative simplicity of manufacturing and assembly, which reduces labor intensity and shortens the production time, which in its turn is economically profitable.

In recent years, dozens of different buildings and structures have been built in Russia using lens-shaped beams with large spans. These space-planning solutions differ favorably by the functionality of architectural forms.

In this paper, one of the reasons to choose a glued wood lenticular truss is the projected building of the exhibition center with a large span of $24 \mathrm{~m}$. The interest is presented both from the scientific and practical point of view and from the architectural and aesthetic aspect, but it is necessary to test for strength under given climatic loads for the realization of this project.

The main features of lens shaped and design trusses efficiency calculation are reflected in the new updated version of SNiP II - 25 - 80 (CR 64.13330 - 2011) [3].

Materials and methods

The initial data for this work was the projected building of the exhibition center with the II level of responsibility, the reliability factor for the intended purpose $\gamma_{n}=0,95$, a heated one, with the temperature and humidity conditions of operation for group A1. The construction area was selected as V snow (Naberezhnye Chelny) with the estimated value of the snow load on the horizontal surface of the earth $3.2 \mathrm{kPa}$. The step of load-bearing structures is $6 \mathrm{~m}$.

Materials of the plate: rib timber - 2nd grade pine according to GOST $8486-86 * \mathrm{E}$; the plating of plywood of FSF grade II/III according to GOST 3916-89; the glue of FRF-50 brand; insulation - thermal insulation plates Rockwool ROOF BATTS, mineral wool on a synthetic binder. Steam insulation - polyethylene film with the thickness of $0.2 \mathrm{~mm}$. The dimensions of the plate in the plan are 5980x1490 mm. The direction of the outer layer fibers of the plywood of the upper and lower shells is assumed to be longitudinal. The wooden frame of the plate is formed by four longitudinal ribs of the boards rigidly glued together with plywood covers. The covers with the thicknesses of $9 \mathrm{~mm}$ are preassembled along the length. The joints of the covers and the ends of the plate have transverse ribs. We calculate the plate as a single-span beam lying on two supports. We take the longitudinal edges after the milling of the upper edges equal to $170 \times 40 \mathrm{~mm}$ with the humidity of $(10 \pm 2) \%$. The relative height of the plate makes $\mathrm{h} / \mathrm{l}=188 / 5920=1 / 30>1 / 35$.

During the design and the calculations, it was necessary to take into account the snow loads that the load-bearing structure would have to withstand. This is necessary so that the roof of the building does not collapse during the operation of the exhibition center. 
After the selection of the lens shaped truss scheme, according to the design requirements, the total size of

the farm was determined:

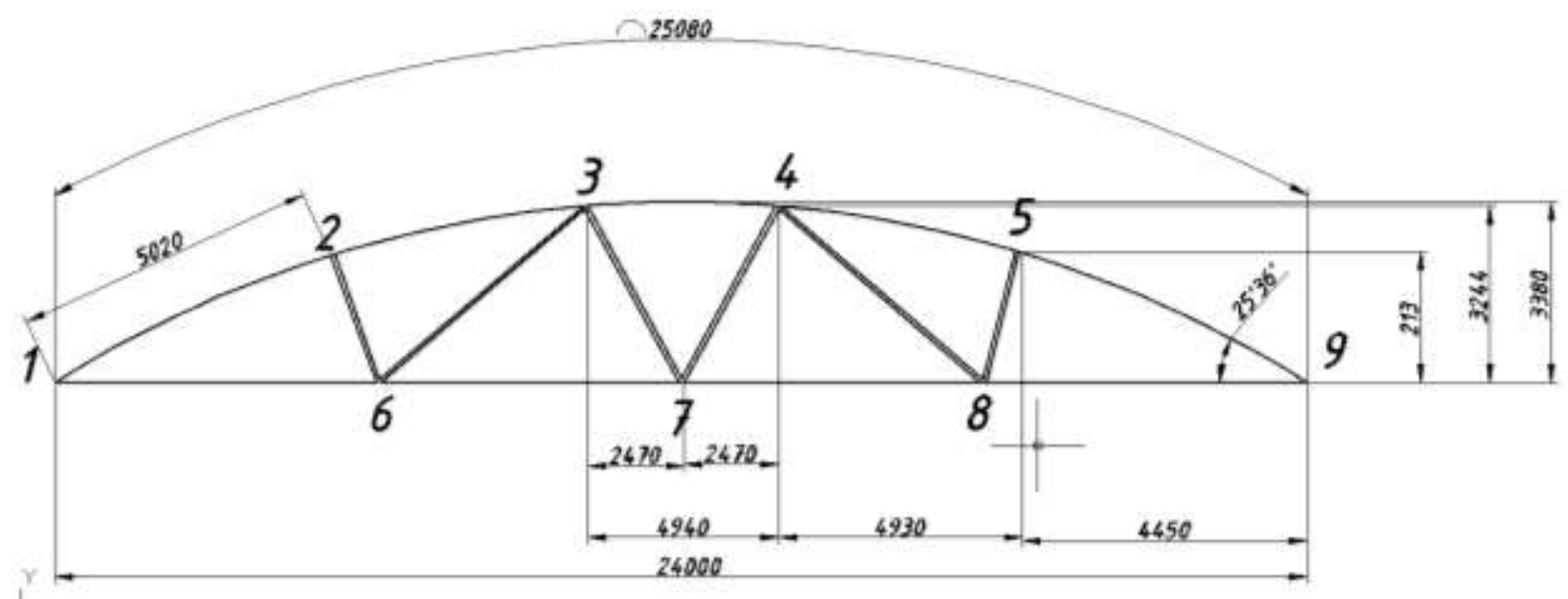

Fig.1. Geometric Layout of the Truss

An estimated span of the truss is $1=24.0 \mathrm{~m}$. We accept a segmented truss with a triangular grid as the span in the axes of 23.7 and the height of $3.38 \mathrm{~m}$.

The choice of such a truss scheme makes it possible to construct considerably smaller cross sections of elements as compared to other types of lattices, which reduces the cost of construction, and this gives an economic effect [3].

The top belt of the lens-shaped truss is continuous, so we take the calculation scheme shown on Figure 1. At that, the curved upper belt is replaced by a straight line one - the nodes of the upper and lower belt are connected by straight lines - chords.

Static calculation of trusses is carried out according to the general rules of structural mechanics for two types of loading:

- constant and temporary (snow) load throughout the span;

- constant load throughout the span and temporary (snow) load on the half-span;
- uniformly distributed constant throughout the span and temporal on eaccording to the law of triangles;

- the constant uniformly distributed throughout the span and distributed in a half-span according to the triangle law;

- the calculation of efforts by the method of cutting out the nodes.

In order to determine the load from the own weight of the roof, the calculation of the deck was carried out according to SP 20.13330.2011, from which it was revealed that uniformly distributed snow load

$s^{I}=13,34 \mathrm{KH} / \mathrm{M}$, is the snow uniformly distributed

$s^{I I}=27 \mathrm{\kappa H} / \mathrm{M}$. The design data are presented in table 1 .

Table 1. Outer Force on the Truss.

\begin{tabular}{|l|c|c|c|}
\hline \multicolumn{1}{|c|}{ Load Type } & Rated load, $\mathrm{kN} / \mathrm{m}$ & $\begin{array}{c}\text { Load reliability } \\
\text { coefficient }\end{array}$ & Design load, $\mathrm{kN} / \mathrm{m}$ \\
\hline Own weight of the plate & 2,94 & - & 4,04 \\
\hline Own weight of the truss & 1,02 & - & 1,122 \\
\hline Constant & 3,96 & - & 5,162 \\
\hline
\end{tabular}

According to CR 20.13330.2011 "Loads and effects" the updated version of SNiP 2.01.07-85* three loading options were considered for the building with folding covers. 

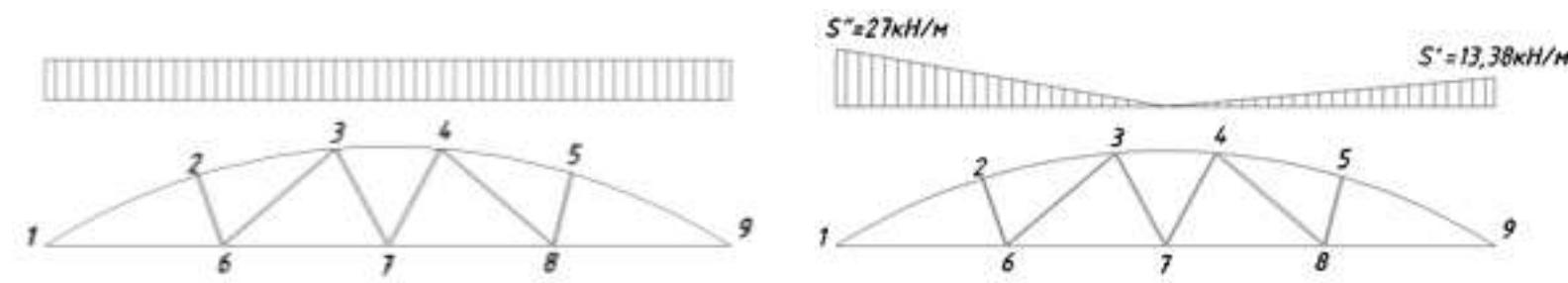

Fig.2. The first variant of snow load scheme

Fig. 3. The second variant of snow load scheme

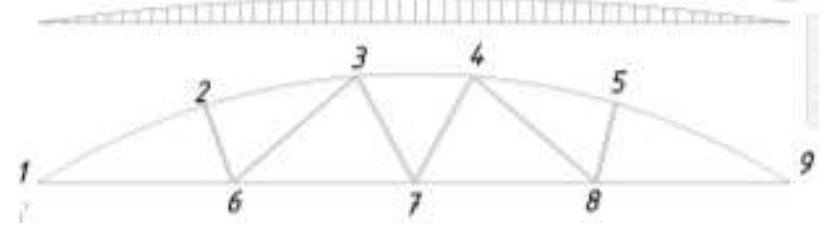

Fig. 3. The third variant of snow load scheme

It was obvious that the snow pressure on the truss according to the third load option is less effective than the first option, because the ordinate of the curvilinear diagram on Figure 4 is less than the value of the uniform pressure shown on Figure 2. Consequently, it did not make sense to consider the third variant of the snow load as a calculated one.

The determination of the computational forces in the elements of the truss was performed by the method of node cutting, that is, by the determination of the forces solving the equilibrium equations of the node separated from the structure. The calculation of a uniform distribution snow load $s^{I}=13,34 \mathrm{KH} / \mathrm{M}$, located on the entire span led to concentrated forces $S_{i}$ in the truss nodes $S_{1}^{I}=S_{9}^{I}, S_{2}^{I}=S_{5}^{I}, S_{3}^{I}=S_{4}^{I}$.

Having checked the received data, it follows that $\sum S_{i}^{I}=(29,68+62,6+65,83) * 2=316,22$

. Supporting reactions: $R_{A}=R_{B}=158,1 \mathrm{kH}$. On the basis of the performed calculations, we checked where $\sum \mathrm{S}_{i}^{\mathrm{I}}=\sum \mathrm{R}_{i}^{\mathrm{I}}=316,22 \mathrm{kH}$.

Further, the uniformly distributed constant load $g=5,162 \mathrm{KH} / \mathrm{M}$ is reduced to concentrated forces $P_{i}$ through the ratio of the distributed constant load and the similar snow one, $K=5,162 / 13,34=0,343, \quad$ therefore, $P_{1}=P_{9}=0,343 * 29,68=10,18 \mathrm{kH}$; $P_{2}=P_{5}=0,343 * 62,6=22,1 \mathrm{kH}$; $P_{3}=P_{4}=0,343 * 65,83=22,6 \kappa \mathrm{H}$;

$$
R_{a}=R_{h}=0,343 * 158.1=54,23 \mathrm{\kappa H}
$$

The distributed snow load of the triangular shape led to concentrated forces $S_{i}^{I I}$ in the truss nodes:

$S_{1}^{I I}=52,54 \mathrm{\kappa H} ; \quad S_{2}^{I I}=77,56 \mathrm{KH} ;$ $S_{3}^{I I}=29,54 \mathrm{\kappa H} ; \quad S_{4}^{I I}=15,5 \mathrm{kH} ;$ $S_{5}^{I I}=38,78 \mathrm{\kappa H} ; \quad S_{9}^{I I}=26,27 \mathrm{\kappa H} ;$ $R_{A}=146,8 \mathrm{\kappa H} ; R_{B}=93,4 \kappa \mathrm{H}$.

According to the performed calculations, the verification is performed, where $\sum \mathrm{S}_{\mathrm{i}}^{\mathrm{II}}=\sum \mathrm{R}_{\mathrm{i}}^{\mathrm{II}}=240,2 \mathrm{KH}$. In each node of the truss we find the efforts from distributive snow load $S^{I}$, similarly the efforts $S^{I I}$ are obtained. The 2 cafcutation results are put into the table 2 .

In the panels of the upper belt the bending moments $M$ appear in addition to the longitudinal forces $\mathrm{N}$. When the upper belt is continuous, the calculated bending moments in the span and on the supports are determined as for a continuous multi-span beam with equal spans. The results of the bending moment terms connection from $g=5,162 \mathrm{KH} / \mathrm{M}$ and $s^{I}=13,34 \mathrm{KH} / \mathrm{M}, \quad$ taking into account $K=0,343$, and the maximum values $M$ in the upper panels from the snow load of the triangular outline are included in Table 2. 
Helix Vol. 8(1): 2516 - 2521

Table 2. Rated force in the elements of the truss in $\mathrm{kN}$.

\begin{tabular}{|c|c|c|c|c|c|c|}
\hline \multirow{2}{*}{$\begin{array}{c}\text { Rod } \\
\text { № }\end{array}$} & \multirow{2}{*}{$\begin{array}{l}\text { Designation of } \\
\text { efforts }\end{array}$} & \multirow{2}{*}{$\begin{array}{c}\text { Efforts from constant } \\
\text { load } \mathrm{g}=5.162 \mathrm{kN} / \mathrm{m} \text {, } \\
\mathrm{K}=0,343\end{array}$} & \multicolumn{2}{|c|}{ Efforts from snow load } & \multicolumn{2}{|c|}{$\begin{array}{c}\text { Calculated combinations } \\
\text { of efforts }\end{array}$} \\
\hline & & & $\begin{array}{c}\text { Continuous } \\
s^{I}=13,34 \mathrm{kH} / \mathrm{M}\end{array}$ & Triangular & Gr.3+gr. 4 & Gr. $3+$ gr. 5 \\
\hline $1-2$ & $\begin{array}{c}N_{1} \\
M_{s}{ }_{a} g \cdot s^{I} \\
M_{N} \\
\sum^{M} M\end{array}$ & $\begin{array}{c}-101,96 \\
11,32 \\
-13,87 \\
-2,55\end{array}$ & $\begin{array}{c}-297,27 \\
33,021 \\
-40,43 \\
-7,409\end{array}$ & $\begin{array}{c}-218,2 \\
54,56 \\
-29,72 \\
24,844\end{array}$ & $\begin{array}{c}-399,23 \\
-9,959\end{array}$ & $\begin{array}{l}-320,16 \\
22,294\end{array}$ \\
\hline $2-3$ & $\begin{array}{c}N_{2} \\
M_{g I_{a \cdot g} l} \\
M_{N} \\
\sum_{M}^{M} M\end{array}$ & $\begin{array}{c}-95,4 \\
14 \\
-13 \\
1\end{array}$ & $\begin{array}{c}-278,08 \\
402 \\
-37,82 \\
2,7\end{array}$ & $\begin{array}{c}-184,72 \\
34,035 \\
-25,2 \\
8,913\end{array}$ & $\begin{array}{c}-373,48 \\
3,3\end{array}$ & $\begin{array}{c}-280,12 \\
9,913\end{array}$ \\
\hline $3-4$ & $\begin{array}{c}N_{3} \\
M_{g} H_{a g \cdot s} I \\
M_{N} M\end{array}$ & $\begin{array}{l}-89,043 \\
13,86 \\
-12,11 \\
1,75\end{array}$ & $\begin{array}{c}-259,6 \\
40,7 \\
-35,31 \\
5,39\end{array}$ & $\begin{array}{l}-145,14 \\
-19,74\end{array}$ & $\begin{array}{c}-348,64 \\
7,14\end{array}$ & $-234,83$ \\
\hline $4-5$ & $\begin{array}{c}N_{4} \\
M_{s} I_{a g} I \\
M_{N} \\
\sum^{M} M\end{array}$ & $\begin{array}{c}-95,4 \\
14 \\
-13 \\
1\end{array}$ & $\begin{array}{c}-278,08 \\
40,52 \\
-37,82 \\
2,7\end{array}$ & $\begin{array}{c}-141,14 \\
17,0175 \\
-19,2 \\
-2,1825\end{array}$ & $\begin{array}{c}-373,48 \\
3,7\end{array}$ & $\begin{array}{l}-236,54 \\
-1,1825\end{array}$ \\
\hline $5-9$ & $\begin{array}{c}N_{5} \\
M_{s{ }_{a} g \cdot s^{l}} \\
M_{N} M\end{array}$ & $\begin{array}{c}-101,96 \\
11,32 \\
-13,87 \\
-2,55\end{array}$ & $\begin{array}{c}-297,27 \\
33,021 \\
-40,43 \\
-7,409\end{array}$ & $\begin{array}{c}-155 \\
27,28 \\
-21,08 \\
6,2\end{array}$ & $\begin{array}{l}-398,53 \\
-9,959\end{array}$ & $\begin{array}{c}-256,96 \\
3,65\end{array}$ \\
\hline $\begin{array}{l}1-6 \\
6-7 \\
7-8 \\
8-9\end{array}$ & $\begin{array}{l}\mathrm{K}_{1} \\
\mathrm{~h}_{2} \\
\mathrm{~h}_{3} \\
\mathrm{~h}_{4}\end{array}$ & $\begin{array}{l}92 \\
93 \\
93 \\
92\end{array}$ & $\begin{array}{c}268,14 \\
271 \\
271 \\
268,14\end{array}$ & $\begin{array}{l}196,8 \\
155 \\
135,4 \\
154,8\end{array}$ & $\begin{array}{c}360,14 \\
364 \\
364 \\
360,14\end{array}$ & $\begin{array}{c}288,8 \\
248 \\
227,6 \\
246,8\end{array}$ \\
\hline $\begin{array}{l}2-6 \\
3-6 \\
3-7\end{array}$ & $\begin{array}{l}D_{1} \\
D_{2} \\
D_{3}\end{array}$ & $\begin{array}{l}3,56 \\
-4,3 \\
1,55\end{array}$ & $\begin{array}{c}10,38 \\
-12,456 \\
4,525\end{array}$ & $\begin{array}{l}-28,96 \\
24,75 \\
-16,2\end{array}$ & $\begin{array}{c}13,94 \\
16,756 \\
6,075\end{array}$ & $\begin{array}{c}-25,4 \\
30,45 \\
-14,65\end{array}$ \\
\hline $\begin{array}{l}4-7 \\
4-8 \\
5-9\end{array}$ & $\begin{array}{l}D_{4} \\
D_{5} \\
D_{6}\end{array}$ & $\begin{array}{l}1,55 \\
-4,3 \\
3,56\end{array}$ & $\begin{array}{c}4,525 \\
-12,456 \\
10,38\end{array}$ & $\begin{array}{c}16,2 \\
4,05 \\
3,375\end{array}$ & $\begin{array}{c}6,075 \\
16,456 \\
13,94\end{array}$ & $\begin{array}{l}14,65 \\
-0,25 \\
6,935\end{array}$ \\
\hline
\end{tabular}


The reliability of the received results was compared with the code of rules SNiP II - 25 - 80 (CR 64.13330 2011) "Wooden structures".

After the finding of forces at each node of the truss from the distributive snow load $S^{I}$ and $S^{I I}$, the longitudinal forces $\mathrm{N}$ and the bending moments $\mathrm{M}$, we selected and checked the section of the truss.

During the selection of the upper belt section, the data from Table No. 2 were used, which shows that the first panel with a snow load is a calculated one. By adopting 2 grade wood and the boards with the cross section of 3,3x18 (after the planing) with an estimated resistance $R_{\mathrm{C}}=R_{\mathrm{K}}=15 \mathrm{Mma}$. The width of the upper belt section and the elements of the lattice were determined from the value of inertia radius and it was determined that the number of layers in the glued element with a thickness of boards of $4.4 \mathrm{~cm}$ is taken to be 12 , and $h=39,6 \mathrm{cM}$. The selected section of the upper belt is tested for strength $\sigma=0,989 \mathrm{\kappa H} / \mathrm{cm}^{2}=9,9 \mathrm{M \Pi a}<R \mathrm{c}=15 \mathrm{Mr}$

. Verification of stability also has a strength test from the plane of the truss upper belt (in the middle of the panel 1-2) during the compression by the force $\mathrm{N}=$ $399.23 \mathrm{kN}$ and the link step $\mathrm{lc}=3 \mathrm{~m}$ $\sigma_{c}=0.62 \mathrm{\kappa H} / \mathrm{cm}^{2}=6,2 \mathrm{M \Pi a}<R \mathrm{c}=15 \mathrm{M} \Pi$

The compressed elements of the truss were tested for stability. Having considered the compressed brace $D_{1}$ with $\mathrm{N}=-25,4 \mathrm{KH}$, we took the section height according to the design conditions equal to $h=13,2 \mathrm{cM}$. The stress in the selected section of the compressed element does not exceed the design resistance $\sigma=1,32 \mathrm{M \Pi l}<R \mathrm{C}=15 \mathrm{M} \Pi$ a. The cross section of compressed braces obtained by calculation is the minimum one necessary to ensure the truss strength.

Stretched wooden elements of the truss were tested for strength. Having calculated the stretched brace of $\mathrm{D}_{2}$ : $\mathrm{N}=30,45 \mathrm{KH}$, we determined that the fastening in the knot is made by the bolts $\mathrm{d}=12 \mathrm{MM}$. The tension in the stretched brace does

$$
\begin{aligned}
& \text { not exceed the design resistance } \\
& \sigma_{p}=\frac{0.16 \mathrm{\kappa H}}{\mathrm{cm}^{2}}<R_{\mathrm{p}}=0.9 * 0.8=0.72 \frac{\mathrm{KH}}{\mathrm{cm}^{2}}
\end{aligned}
$$

The lower belt is taken from 2 steel corners $90 \times 90 \times 6$. The upper belt is secured in the assembly with one structural bolt $\mathrm{d}=16 \mathrm{~mm}$. Pressure plate is calculated approximately as the beam of T-section 18 $\mathrm{cm}$ long, $9 \mathrm{~cm}$ wide, with the edge of $60 \times 8 \mathrm{~mm}$. Having calculated the base plate, we took the dimensions $\mathrm{A}=20 \times 25 \mathrm{~cm}, \delta=12 \mathrm{MM}$. According to the performed calculations, it can be concluded that the accepted cross-section in terms of ensuring the necessary stability, was selected correctly.

\section{Conclusions}

According to the results of the performed work, it can be concluded that the selected design, namely the wooden segmented lens farm, can be chosen as a cover for a building with the span of $24 \mathrm{~m}$, in the construction area - V snow (Naberezhnye Chelny) with the estimated value of the snow load on the horizontal the ground surface of $3.2 \mathrm{kPa}$.

And although the obtained results do not exceed the normative values of the design load, the additional reinforcement of the support area of the truss support units should be considered possible during the design of buildings and structures with large spans or in the cases of snow loading exceeding the normalized values for the $\mathrm{V}$ snow area of construction [4]. In this work, the technical and economic indicators for the consumption of materials were not considered due to the distribution of the belt material over the span, and this once again favorably distinguishes lens-shaped trusses from the traditional building structures of the coating [5].

And also issues about the durability of wooden constructions and the protection from ignition remained uncovered. But with existing standards, the lifetime of wooden structures increases [6,7].

\section{Acknowledgements}

The work is performed according to the Russian Government Program of Competitive Growth of Kazan Federal University.

\section{References}

1. Richmond Olympic Oval [Electronic resource] // Naturally: wood. - Access terms: www.naturallywood.com/sites/default/files/RichmondOlympic-Oval-Case-Study.pdf

2. S.B. Turkovsky, A.A. Pogoreltsev, I.L. Eknadosyan. The choice of the constructive scheme for lens trusses from glued wood. Construction materials. № 5, 2003. 18-18 p.

3. Code of regulations CR 64.13330 - 2011 (updated version of SNiP II - 25 - 80) "Wooden structures" - M.: OJSC "TsPP" 2011.

4. Zonina S.V., Zonin E.A. Features of lensshaped trusses operation from LVL wood. New science: Strategies and vectors of development. 2016. №10-1. pp. 105-108.

5. Wooden structures. Examples of calculation and design: a tutorial / ed. by D.K. Arleninov. - M.; ASV Publishing House, 2006.

6. Guidelines ensuring the durability of wooden glued structures during the exposure to microclimate of 
buildings for various purposes and atmospheric factors. - Moscow: Stroyizdat, 1981. - p. 96.

7. Turkovsky S.B., Lomakin A.D., Pogoreltsev A.A. Dependence of glued wooden structure state on the humidity of the surrounding air // Industrial and civil construction. Proceedings of the institute. Moscow: TsNIISK named after V.A. Kucherenko. 2012. - №3. - pp. 30-32
8. Turkovsky S.B. Rational applications of loadbearing glued wooden structures (GWS) "TsNIISK Systems" / S.B. Turkovsky, A.A. Pogorel'tsev // The collection of scientific works "Modern building constructions of metal and wood" - OGASA. - Issue № 15. - Part 2. - Odessa, 2011. - pp. 217-225.

9. Code of regulations CR 20.13330.2011 "Loads and effects." (updated version of SNiP 2.01.0785*) - M.: OJSC "TsPP" 2011. 